\title{
PELAKSANAAN PELAYANAN OLEH TENAGA KEFARMASIAN BERDASARKAN PERATURAN MENTERI KESEHATAN REPUBLIK INDONESIA NOMOR 30 TAHUN 2014 TENTANG STANDAR PELAYANAN KEFARMASIAN DI PUSKESMAS (Studi di Puskesmas Kabupaten Purbalingga) Oleh: R. Adi Soeprijanto ${ }^{164}$
}

\begin{abstract}
Pharmaceutical service is an integrated activity with a view to identifying, preventing, and resolving drug related issues. Limited number of pharmacist, misappropriation of drugs, availability of drugs and legal certainty of contract pharmacist are inhibiting factors of pharmaceutical services at Public Health Center.

This research is in the form of juridical normative-empirical by using secondary and primary data. Secondary data source from library study as secondary legal materials and primary data source from observation and interview as primary legal material.

The results showed pharmacist is responsible for pharmaceutical services in Public Health Center, both clinical pharmacy and drug management. Drug shortages occur because the stock is empty from district health office and the presence of expired drugs comes from provincial stock buffer. Technical implementation of pharmaceutical service using guidelines in accordance with legislation. Appointment of contract worker by unauthorized persons caused administrative violations. Registration certificate and practice license are the basic of legal certainty for pharmacist.

Key words: Pharmaceutical Service, Pharmacist, Public Health Center
\end{abstract}

\begin{abstract}
Abstrak
Pelayanan kefarmasian merupakan kegiatan yang terpadu dengan tujuan untuk mengidentifikasi, mencegah dan menyelesaikan masalah yang berkaitan dengan obat. Jumlah apoteker yang terbatas, salah pemberian obat, ketersediaan obat, dan kepastian hukum apoteker kontrak merupakan faktor penghambat pelayanan kefarmasian di Puskesmas.

Penelitian ini berbentuk yuridis normatif-empiris, dengan menggunakan data sekunder dan data primer. Sumber data sekunder berupa studi pustaka berbentuk bahan hukum sekunder sedangkan data primer berupa observasi dan wawancara berbentuk bahan hukum primer.

Hasil penelitian menunjukkan apoteker sebagai penanggung jawab pelayanan kefarmasian di Puskesmas, baik farmasi klinik maupun pengelolaan obat. Kekurangan obat terjadi karena stok dari Dinas Kesehatan Kabupaten yang kosong dan adanya obat kadaluwarsa berasal dari buffer stock provinsi. Teknis pelaksanaan pelayanan kefarmasian menggunakan pedoman yang sesuai dengan peraturan perundangundangan. Pengangkatan tenaga kontrak oleh pihak yang tidak berwenang menyebabkan terjadinya pelanggaran administrasi. Surat Tanda Registrasi (STR) dan Surat Izin Praktik (SIP) merupakan dasar kepastian hukum bagi tenaga kefarmasian. Kata kunci : Pelayanan Kefarmasian, Tenaga Kefarmasian, Puskesmas
\end{abstract}

${ }^{164}$ UPTD Puskesmas Rembang, Purbalingga, Email : adhyez57@yahoo.com 


\section{A. Pendahuluan}

Kesehatan adalah salah satu parameter untuk mengukur keberhasilan pembangunan manusia. ${ }^{165}$ Tanpa kesehatan manusia tidak akan produktif untuk hidup layak secara ekonomi dan menjalani pendidikan yang baik. Begitu juga tanpa ekonomi yang baik, manusia tidak akan dapat memperoleh pelayanan kesehatan yang baik serta pendidikan yang baik. Tanpa pendidikan yang baik, manusia juga tidak bisa mengerti kesehatan serta mendapatkan ekonomi yang baik. Ketiga parameter ini saling berhubungan dan tidak bisa dipisahkan satu sama lain. Kesehatan merupakan hak asasi manusia dan salah satu unsur kesejahteraan yang harus diwujudkan sesuai dengan citacita bangsa Indonesia yang dimaksud dalam Pancasila dan Undang-Undang Dasar Negara Republik Indonesia Tahun 1945. Dijelaskan dalam UndangUndang Nomor 36 Tahun 2009 tentang Kesehatan bahwa kesehatan adalah keadaan sehat, baik secara fisik, mental, spiritual maupun social yang memungkinkan setiap orang untuk hidup produktif secara sosial dan ekonomis. Pasal $28 \mathrm{H}$ ayat (1) Undang-Undang Dasar 1945 dengan jelas menyatakan bahwa setiap orang berhak hidup sejahtera lahir dan batin, bertempat

${ }^{165}$ Sri Siswati, 2013, Etika dan Hukum Kesehatan Dalam Perspektif UndangUndang Kesehatan, PT. Raja Grafindo Persada, Jakarta, hal. 2-3. tinggal, dan mendapat lingkungan hidup yang baik dan sehat serta berhak memperoleh pelayanan kesehatan. Artinya, kesehatan sebagai kebutuhan dasar manusia merupakan hak bagi setiap warga negara.

Hukum merupakan sarana untuk mewujudkan hak-hak manusia dalam memenuhi kebutuhannya. Hakikat hukum adalah perlindungan kepentingan manusia, termasuk dalam mewujudkan kesehatan. ${ }^{166}$ UndangUndang No. 36 tahun 2014 tentang Tenaga Kesehatan pada Pasal 11 ayat (6) menyebutkan jenis tenaga kesehatan yang termasuk dalam kelompok tenaga kefarmasian adalah Apoteker dan Tenaga Teknis Kefarmasian (TTK). Definisi apoteker dan Tenaga Teknis Kefarmasian terdapat dalam Peraturan Pemerintah (PP) No. 51 tahun 2009 tentang Pekerjaan Kefarmasian dan Peraturan Menteri Kesehatan Republik Indonesia Nomor 30 Tahun 2014 tentang Standar Pelayanan Kefarmasian di Puskesmas, yaitu apoteker adalah sarjana farmasi yang telah lulus sebagai apoteker dan telah mengucapkan sumpah jabatan apoteker sedangkan TTK adalah tenaga yang membantu apoteker dalam menjalani pekerjaan kefarmasian yang terdiri atas Sarjana Farmasi, Ahli Madya Farmasi, Analis Farmasi dan Tenaga Menengah Farmasi/Asisten Apoteker.

166 Cecep Triwibowo, 2014, Etika dan Hukum Kesehatan, Nuha Media, Yogyakarta, hal. 13. 
Dalam menjalankan pelayanan kefarmasian di Puskesmas, apoteker dapat dibantu oleh Tenaga Teknis Kefarmasian (TTK) yang telah memiliki Surat Izin Kerja.

Standar pelayanan kefarmasian di Puskesmas meliputi standar pelayanan farmasi klinik dan standar pengelolaan obat dan bahan medis habis pakai. Penyelenggaraan standar pelayanan kefarmasian di Puskesmas harus didukung oleh sumber daya manusia, sarana dan prasarana yang memadai. Penyelenggaraan pelayanan kefarmasian di Puskesmas minimal harus dilaksanakan oleh 1 (satu) orang tenaga apoteker sebagai penanggung jawab, yang dapat dibantu oleh Tenaga Teknis Kefarmasian (TTK) sesuai kebutuhan. ${ }^{167}$ Jumlah kebutuhan apoteker di Puskesmas dihitung berdasarkan rasio kunjungan pasien, baik rawat inap maupun rawat jalan serta memperhatikan pengembangan Puskesmas. Rasio untuk menentukan jumlah apoteker di Puskesmas adalah 1 (satu) apoteker untuk 50 (lima puluh) pasien per hari.

Menurut Data Dasar Puskesmas dan Rumah Sakit Provinsi Jawa Tengah tahun $2015^{168}$, jumlah tenaga apoteker

\footnotetext{
167 Kementerian Kesehatan Republik Indonesia, 2015, Standar Pelayanan Kefarmasian di Puskesmas, Jakarta, hal. 25.

168 Dinas Kesehatan Provinsi Jawa Tengah, 2016, Data Dasar Puskesmas danm Rumah Sakit Provinsi Jawa Tengah Tahun 2015, http://www.dinkesjatengprov.go.id.,
}

yang bekerja di Puskesmas berjumlah $40,34 \%$ dari jumlah total 875 Puskesmas di Jawa Tengah. Terbatasnya jumlah apoteker di Puskesmas dapat menimbulkan suatu permasalahan dalam pelayanan kefarmasian di Puskesmas. Pelayanan kefarmasian yang dilaksanakan oleh tenaga kefarmasian harus dilakukan sesuai dengan prosedur.

Data pada Laporan Peta Nasional Keselamatan Pasien (Kongres PERSI 2007) menunjukkan kesalahan pemberian obat menempati urutan pertama sebesar $24,8 \%$ dari 10 kasus. ${ }^{169}$ Sebagai salah satu contoh kasus adalah yang terjadi di Klinik PMI Purwokerto. Imam Bagus Pranoto (30) warga Jalan Sukadamai RT 3/RW 3 Kelurahan Karangpucung mengadu ke Komisi D DPRD Banyumas atas tindakan salah pemberian obat kepada anaknya, Prasraya Al Ghazali Langlang Buana oleh pihak Klinik PMI Purwokerto, hingga menyebabkan anaknya seperti kejang-kejang. ${ }^{170}$ Kasus lain yang terjadi adalah di Puskesmas Buleleng III Bali, yaitu salah pemberian obat oleh seorang bidan desa yang saat itu bertugas di bagian farmasi. Dokter

diakses pada tanggal 3 Januari 2017.

169 Dinas Kesehatan Provinsi Jawa Tengah, 2016, Data Dasar Puskesmas dan Rumah Sakit Provinsi Jawa Tengah Tahun 2015, http://www.dinkesjatengprov.go.id.,

170 Anonim, 2016, Dugaan Salah Obat Pada Pasien, PMI Klaim Sudah Sesuai Aturan, http://www.radarbanyumas.co.id/, diakses pada tanggal 7 Mei 2017. 
memberikan resep obat tetes mata tetapi pembacaan resep oleh petugas adalah obat tetes telinga. Saat itu petugas bagian farmasi sedang diberikan tugas tambahan sehingga digantikan oleh petugas bidan desa yang melayani resep. ${ }^{171}$ Sementara contoh kasus lainnya di luar negeri adalah 3 (tiga) orang asisten apoteker (Tenaga Teknis Kefarmasian) di Cebu, Filipina diduga melakukan kelalaian dalam meracik (dispensing) obat resep, dimana memberikan Eltroxin (Levothyroxine) yang seharusnya memberikan antibiotik Cefalexin. Kelalaian ini mengakibatkan cedera fisik yang serius yang menyebabkan pasien mengalami hipertiroidisme. ${ }^{172}$

Dalam survey pendahuluan di Kabupaten Purbalingga Provinsi Jawa Tengah, berdasarkan data sementara dari Seksi Kefarmasian Dinas Kesehatan Kabupaten Purbalingga, dari total 22 Puskesmas tercatat jumlah tenaga kefarmasian di Puskesmas Kabupaten Purbalingga sampai dengan bulan Oktober 2016 sebanyak 17 orang apoteker terdiri dari 5 orang apoteker dengan status PNS dan 12 orang

\footnotetext{
171 Mudiarta, 2017, Bagian Farmasi Salah Baca Resep, http://www.balipost.com/news/2017/05 104/7655, diakses pada tanggal $7 \mathrm{Mei}$ 2017.

9 Anonim, 2017, 3 Asisten Apoteker Salah Memberikan Obat Hingga Sebabkan Cedera Fisik Serius, http://www.farmasetika.com>Dispensin g>Edukasi, diakses pada tanggal 7 Mei 2017
}

apoteker dengan status kontrak yang diangkat oleh Kepala Dinas Kabupaten Purbalingga. Di dalam Undang-Undang No. 5 tahun 2014 tentang Aparatur Sipil Negara (ASN), pada Pasal 2 ayat (1) menyebutkan bahwa pegawai ASN adalah Pegawai Negeri Sipil (PNS) dan Pegawai Pemerintah Dengan Perjanjian Kerja (PPPK) yang diangkat oleh Pejabat Pembina Kepegawaian (PPK) dan diserahi tugas dalam suatu jabatan pemerintahan atau diserahi tugas negara lainnya dan digaji berdasarkan peraturan perundang-undangan.

Dengan demikian, status apoteker kontrak yang bekerja di Puskesmas seharusnya diangkat oleh Pejabat Pembina Kepegawaian (PPK), dimana PPK di tingkat daerah adalah seorang bupati, agar apoteker kontrak tersebut memiliki legalitas yang jelas sehingga kepastian hukumnya dalam menjalankan pelayanan kefarmasian terjamin. Jumlah tenaga apoteker tersebut juga belum memenuhi amanah dari Peraturan Menteri Kesehatan Republik Indonesia Nomor 30 Tahun 2014 tentang Standar Pelayanan Kefarmasian di Puskesmas, dimana setiap Puskesmas harus memiliki apoteker sebagai penanggung jawab pelayanan kefarmasian di Puskesmas.

Selain itu, ada beberapa jenis obat yang tidak tersedia di Puskesmas Kabupaten Purbalingga, seperti Diazepam injeksi, Stesolid rektal suppo, dan Ringer Laktat. Diazepam injeksi dan 
Stesolid rektal suppo merupakan obat golongan psikotropika yang berfungsi sebagai anti depresan dan kejang demam, dimana jika terdapat pasien dengan gejala kejang akibat demam yang tinggi sementara obat tersebut tidak tersedia di Puskesmas, maka hal ini akan menghambat proses pengobatan bahkan dapat mengancam nyawa pasien. Sementara Ringer Laktat merupakan cairan infus yang berfungsi sebagai cairan elektrolit pada pengobatan dehidrasi pasien rawat inap di Puskesmas. Kekosongan obat-obatan tersebut menunjukkan bahwa ada permasalahan dalam kegiatan pengelolaan obat di Puskesmas yang berimbas pada pelayanan farmasi klinik.

\section{B. Perumusan Masalah}

Berdasarkan uraian di atas, maka dalam penelitian ini dirumuskan permasalahan sebagai berikut: Pertama, bagaimanakah pelaksanaan pelayanan oleh tenaga kefarmasian berdasarkan Peraturan Menteri Kesehatan Republik Indonesia Nomor 30 Tahun 2014 tentang Standar Pelayanan Kefarmasian di Puskesmas Kabupaten Purbalingga, Kedua, bagaimanakah kepastian hukum tenaga kefarmasian yang menjalankan pelayanan di Puskesmas Kabupaten Purbalingga.

\section{Metode Penelitian}

Metode dalam penelitian ini menggunakan metode penelitian hukum normatif-empiris. Menurut Abdulkadir
Muhammad $^{173}$, penelitian hukum normatif-empiris (applied law research/terapan) merupakan penelitian untuk mengkaji pelaksanaan atau implementasi ketentuan hukum positif (perundang-undangan) secara faktual pada setiap peristiwa hukum tertentu yang terjadi dalam masyarakat guna mencapai tujuan yang telah ditentukan. ${ }^{174}$ Lokasi penelitian di Puskesmas Kabupaten Purbalingga Provinsi Jawa Tengah dan penentuan sampel lokasi diambil berdasarkan cluster random sampling. Sumber data dalam penelitian ini adalah data sekunder dan data primer. Data sekunder yang digunakan terdiri dari: bahan hukum primer $^{175}$ dan bahan hukum sekunder. Sedangkan data primer dilakukan dengan observasi dan wawancara.

\section{Pembahasan}

1. Pelaksanaan Pelayanan Oleh Tenaga Kefarmasian

Berdasarkan Peraturan Menteri Kesehatan Republik Indonesia Nomor 30 Tahun 2014 tentang Standar Pelayanan Kefarmasian di Puskesmas.

173 Abdulkadir Muhammad, 2004, Hukum dan Penelitian Hukum, PT. Citra Aditya Bakti, Bandung, hal. 53.

174 Sugiyono, 2008, Memahami Penelitian Kualitatif, Alfabeta, Bandung, hal. 94.

175 Salim HS, 2014, Penerapan Teori Hukum pada Penelitian Tesis dan Disertasi, Rajawali Pers, Jakarta, hal.16. 
Pelayanan kefarmasian pada saat ini telah berubah paradigmanya dari orientasi obat kepada pasien yang mengacu pada asuhan kefarmasian (pharmaceutical care). ${ }^{176}$ Sebagai konsekuensi dari perubahan orientasi tersebut, tenaga kefarmasian dituntut untuk meningkatkan pengetahuan, keterampilan, dan perilaku agar dapat berinteraksi langsung dengan pasien. Pelayanan kefarmasian menurut Peraturan Menteri Kesehatan Republik Indonesia Nomor 30 tahun 2014 pada Pasal 1 ayat (3) adalah suatu pelayanan langsung dan bertanggung jawab kepada pasien yang berkaitan dengan sediaan farmasi dengan maksud mencapai hasil yang pasti untuk meningkatkan mutu kehidupan pasien. Pelayanan kefarmasian di puskesmas meliputi dua kegiatan, yaitu kegiatan yang bersifat manajerial yang berupa pengelolaan obat dan bahan medis habis pakai dan kegiatan pelayanan farmasi klinik. Kegiatan tersebut harus didukung oleh sumber daya manusia dan sarana prasarana yang memadai.

a. Pelayanan Farmasi Klinik Landasan hukum pelayanan farmasi klinik di Puskesmas

${ }^{176}$ Direktorat Jenderal Bina Farmasi dan Alat Kesehatan, 2006, Pedoman Pelayanan Kefarmasian di Puskesmas, Departemen Kesehatan Republik Indonesia,Jakarta, hal. 9.
Kabupaten Purbalingga

mengacu pada Pasal 3

Peraturan Menteri Kesehatan

Republik Indonesia Nomor 30

Tahun 2014 tentang Standar

Pelayanan Kefarmasian di

Puskesmas. Secara umum, tahapan pelayanan farmasi klinik sesuai dengan Peraturan Menteri Kesehatan Republik Indonesia Nomor 30 Tahun 2014 tentang Standar Pelayanan Kefarmasian di Puskesmas yang meliputi kegiatan pengkajian resep, penyerahan obat, pemberian informasi obat, Pelayanan Informasi Obat (PIO), konseling, ronde/visite pasien (khusus Puskesmas Rawat Inap), pemantauan dan pelaporan efek samping obat, dan pemantauan terapi obat menitikberatkan pada pelayanan resep dan pemberian informasi yang berkaitan dengan obat-obatan. Teknis pelayanan farmasi klinik pada tahap pelayanan resep dan Pelayanan Informasi Obat (PIO) dapat mengacu Pedoman Pelayanan Kefarmasian di Puskesmas tahun 2006, yaitu: $:^{177}$

a) Pelayanan resep, resep adalah permintaan tertulis dari

177 Ibid., hal. 14-16. 
dokter, dokter gigi, dokter hewan kepada apoteker untuk menyediakan dan menyerahkan obat bagi pasien sesuai peraturan

perundangan yang berlaku. Pelayanan resep meliputi penerimaan resep, peracikan obat, dan penyerahan obat disertai pemberian informasi obat.

b) Pelayanan Informasi Obat (PIO), pada pelayanan informasi obat, harus dilakukan dengan benar, jelas, mudah dimengerti, akurat, tidak bias, etis, bijaksana, dan terkini dalam rangka upaya penggunaan obat yang rasional oleh pasien. Sumber informasi obat dapat berasal dari Famakope Indonesia (FI), Informasi Spesialite Obat (ISO), Informasi Obat Nasional Indonesia (IONI), Farmakologi dan Terapi, serta buku-buku lainnya. Informasi obat juga dapat diperoleh dari setiap kemasan atau brosur obat.

c) Pada pelaksanaan konseling, teknis pelaksanaan mengacu pada Pedoman Konseling Pelayanan Kefarmasian di Sarana Kesehatan tahun $2007 . \quad K o n s e l i n g$ adalah suatu kegiatan bertemu dan berdiskusinya

seseorang yang
membutuhkan (client) dan seseorang yang memberikan

(conselor) dukungan dan dorongan

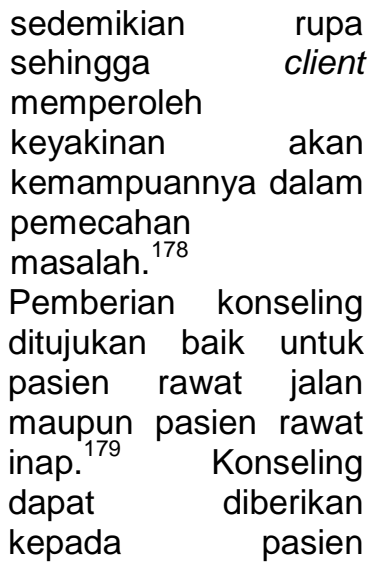
langsung atau melalui perantara. Perantara yang dimaksud disini adalah keluarga pasien, pendamping pasien, perawat pasien, atau siapa saja yang bertanggung jawab dalam perawatan pasien. Pemberian konseling melalui perantara diberikan jika pasien tidak mampu mengenali obat-obatan dan terapinya, pasien pediatrik, dan pasien geriatrik. Pemberian konseling untuk pasien rawat jalan dapat diberikan pada saat pasien mengambil obat di apotik, puskesmas, dan sarana kesehatan lain.

d) Pada pelaksanaan ronde/visite pasien, teknis pelaksanaan mengacu pada Pedoman Visite tahun $2011 . \quad K e g i a t a n$ pelayanan

kefarmasian yang berorientasi pada pasien adalah praktik apoteker ruang rawat (ward pharmacist)

${ }^{178}$ Direktorat Jenderal Bina Kefarmasian dan Alat Kesehatan, 2007, Pedoman Konseling Pelayanan Kefarmasian di Sarana Kesehatan, Departemen Kesehatan RI, Jakarta, hal. 4.

${ }^{179}$ Ibid., hal. 8. 
1187 | Jurnal Idea Hukum

Vol. 4 No. 2 Oktober 2018

Magister Hukum Fakultas Hukum Universitas Jenderal Soedirman

dengan visite sebagai

salah 180 satu

aktivitasnya. ${ }^{180}$ Visite

apoteker adalah

kunjungan rutin yang

dilakukan apoteker

kepada pasien di

ruang rawat dalam

rangka mencapai hasil

terapi (clinical

outcome) yang lebih

baik. Aktivitas visite

dapat dilakukan

secara mandiri atau

kolaborasi secara aktif

dengan tim dokter dan

profesi kesehatan

lainnya dalam proses

penetapan keputusan

terkait terapi obat

pasien. Visite yang

dilakukan oleh

apoteker meliputi

kegiatan: ${ }^{181}$ identifikasi

masalah terkait

penggunaan obat,

rekomendasi

penyelesaian/pencega

han masalah terkait

penggunaan obat

dan/atau pemberian

informasi obat dan

Pemantauan

implementasi

rekomendasi dan hasil terapi pasien.

e) Pada kegiatan

Monitoring Efek

Samping Obat

(MESO), teknis

pelaksanaan dapat

mengacu pada

Pedoman Monitoring

Efek Samping Obat

(MESO) Bagi Tenaga

Kesehatan tahun

2012. Monitoring Efek

Samping Obat

(MESO) oleh tenaga

kesehatan

di

\footnotetext{
${ }^{180}$ Direktorat Jenderal Bina Kefarmasian dan Alat Kesehatan, 2011, Pedoman Visite, Kementerian Kesehatan RI, Jakarta, hal. 1.

${ }^{181}$ Ibid., hal. 3-4.
}

$$
\begin{array}{lr}
\text { Indonesia } & \text { masih } \\
\text { bersifat } & \text { sukarela } \\
\text { (voluntary } & \text { reporting) } \\
\text { dengan menggunakan } & \text { mogulan } \\
\text { formulir } & \text { pelaporan }
\end{array}
$$

ESO berwarna kuning,

yang dikenal sebagai

form kuning. ${ }^{182}$

Monitoring tersebut

dilakukan terhadap

seluruh obat beredar

dan digunakan dalam

pelayanan kesehatan

di Indonesia. Aktivitas

monitoring ESO dan

juga pelaporannya

oleh sejawat tenaga

kesehatan sebagai

healthcare provider

merupakan suatu tool

yang dapat digunakan

untuk mendeteksi

kemungkinan

terjadinya ESO yang

serius dan jarang

terjadi.

f) Pada kegiatan

Pemantauan Terapi

Obat (PTO), teknis

pelaksanaan mengacu

pada Pedoman

Pemantauan Terapi

Obat tahun 2009.

Pemantauan Terapi

Obat (PTO) adalah

suatu proses ysng

mencakup kegiatan

untuk memastikan

terapi obat yang

aman, efektif dan

rasional bagi

pasien. ${ }^{183}$ Kegiatan

tersebut mencakup

pengkajian pilihan

182 Direktorat Pengawasan Distribusi Produk Terapetik dan PKRT, 2012, Pedoman Monitoring Efek Samping Obat (MESO) Bagi Tenaga Kesehatan, Badan POM RI, Jakarta, hal. 13.

${ }^{183}$ Direktorat Jenderal Bina Kefarmasian dan Alat Kesehatan, 2009, Pedoman Pemantauan Terapi Obat, Departemen Kesehatan RI, Jakarta, hal. 1. 
obat, dosis, cara pemberian obat, respon terapi obat, reaksi obat yang tidak dikehendaki (ROTD), dan rekomendasi perubahan atau alternatif terapi. Pemantauan terapi obat harus dilakukan secara berkesinambungan dan dievaluasi secara teratur pada periode tertentu agar keberhasilan ataupun kegagalan terapi dapat diketahui. Pasien yang mendapatkan terapi obat mempunyai resiko mengalami masalah terkait obat. Kompleksitas penyakit dan penggunaan obat serta respon pasien yang sangat individual meningkatkan

munculnya masalah terkait obat. Hal tersebut menyebabkan perlunya dilakukan PTO dalam praktik profesi untuk mengoptimalkan efek terapi dan meminimalkan efek yang tidak dikehendaki.

g) Pelaksanaan evaluasi penggunaan obat dapat mengacu pada Modul Materi Pelatihan Manajemen Kefarmasian di Puskesmas tahun 2010 dan Modul Penggunaan Obat Rasional tahun 2011. Evaluasi merupakan serangkaian prosedur untuk menilai suatu program dan memperoleh informasi tentang keberhasilan pencapaian tujuan, kegiatan, hasil dan dampak serta biayanya. ${ }^{184}$

Fokus utama dari evaluasi adalah mencapai perkiraan yang sistematis dari dampak program. Evaluasi penggunaan obat merupakan kegiatan untuk mengevaluasi penggunaan obat secara terstruktur dan berkesinambungan untuk menjamin obat yang digunakan sesuai indikasi, efektif, aman dan terjangkau (rasional). Penyelenggaraan pelayanan kefarmasian di Puskesmas dipimpin oleh seorang apoteker sesuai dengan Pasal 6 Peraturan Menteri Kesehatan Republik Indonesia Nomor 30 Tahun 2014 tentang Standar Pelayanan Kefarmasian di Puskesmas. Ditinjau dari hasil penelitian lapangan dan wawancara, penanggung jawab pelayanan farmasi klinik dipegang oleh apoteker. Jika di suatu Puskesmas terdapat apoteker yang berstatus kontrak dan TTK yang berstatus PNS, maka TTK sebagai penanggung jawab penuh terhadap jalannya pelayanan kefarmasian sedangkan apoteker kontrak bertanggung jawab hanya pada pelayanan farmasi klinik.

${ }^{184}$ Direktorat Jenderal Bina Kefarmasian dan Alat Kesehatan, 2010, Materi Pelatihan Manajemen Kefarmasian di Puskesmas, Kementerian Kesehatan RI, Jakarta, hal. 34 . 
Keterangan dari tenaga kefarmasian di Puskesmas dan Kepala Dinas Kesehatan Kabupaten Purbalingga merujuk pada status ketenagaannya, yaitu antara PNS dan kontrak. Sementara keterangan dari Kepala Seksi Kefarmasian Dinas Kesehatan Kabupaten Purbalingga berbeda pendapat, yaitu penanggung jawab pelayanan kefarmasian tetap menjadi tanggung jawab apoteker walaupun statusnya kontrak. Ditinjau dari Penjelasan Pasal 51 ayat (3) Peraturan Pemerintah Republik Indonesia Nomor 51 Tahun 2009 tentang Pekerjaan Kefarmasian menjelaskan bahwa "Dalam hal apoteker dibantu oleh Tenaga Teknis Kefarmasian, pelaksanaan pelayanan kefarmasian tetap dilakukan oleh apoteker dan tanggung jawab tetap berada di tangan apoteker." Hal ini jelas, bahwa penanggung jawab pelayanan kefarmasian di Puskesmas harus seorang apoteker tanpa memandang status ketenagaan sebagai PNS atau kontrak.

Apoteker bertanggung jawab untuk menyiapkan dan menyerahkan obat sesuai permintaan tertulis dari dokter. Dokter wajib menuliskan resep dengan jelas dan lengkap, sementara jika resep tersebut tidak jelas dan lengkap, apoteker berkewajiban untuk mengkonfirmasi kembali kepada dokter penulis resep. Beberapa masalah yang didapatkan pada resep dokter antara lain $:^{185}$

1. meresepkan obat bukan yang sebenarnya dimaksudkan, menulis dengan tidak jelas/tidak terbaca, menulis nama obat menggunakan singkatan yang tidak terstandarisasi, menuliskan interaksi obat yang ambigu,

2. meresepkan suatu tablet yang tersedia lebih dari satu kekuatan obat tersebut, tidak menuliskan rute pemberian untuk obat yang dapat diberikan dengan lebih dari satu rute, tidak mencantumkan tanda tangan penulis resep, tidak mencantumkan berat badan pada pasien anak-anak.

Dalam bahasa medis, hal ini disebut sebagai medication error dalam penulisan resep pada tahap prescrebing error. ${ }^{186}$ Jika apoteker menerima resep yang meragukan dan tidak terbaca tetapi tetap menyiapkan obat dengan cara perkiraan tanpa mengkomunikasikankembali dengan dokter penulis resep, dan ternyata obat yang diberikan

\footnotetext{
${ }^{185}$ Wendi Muh. Fadhli, Siti Anisah, 2016, Tanggung Jawab Hukum Dokter dan Apoteker Dalam Pelayanan Resep, Media Farmasi Vol. 13 No. 1 Maret 2016, hal. 76. ${ }^{186}$ Ibid.
} 
salah, apoteker telah melakukan

kelalaian, artinya perbuatan

tersebut dapat merugikan pihak pasien.

b. Pengelolaan Obat dan Bahan

Medis Habis Pakai

Pengelolaan obat dan bahan medis habis pakai pada teknis pelaksanaannya, dapat mengacu pada Pedoman Pengelolaan Obat Publik dan Perbekalan Kesehatan tahun 2004. Kegiatan tersebut dirinci sebagai berikut :

1) Perencanaan, adalah suatu proses kegiatan seleksi obat dan perbekalan kesehatan untuk menentukan jumlah obat dalam rangka pemenuhan kebutuhan Puskesmas. ${ }^{187}$ Ketepatan dan kebenaran data di Puskesmas akan berpengaruh terhadap ketersediaan obat dan perbekalan kesehatan secara keseluruhan di Kabupaten/Kota. Tujuan perencanaan adalah untuk mendapatkan perkiraan jenis dan jumlah obat dan perbekalan kesehatan yang mendekati kebutuhan, meningkatkan penggunaan obat secara rasional dan meningkatkan efisiensi penggunaan obat.

2) Permintaan Obat, sumber penyediaan obat di Puskesmas adalah berasal dari Dinas Kesehatan Kabupaten/Kota. ${ }^{188}$ Obat yang diperkenankan untuk disediakan di Puskesmas

187 Direktorat Jenderal Pelayanan Kefarmasian dan Alat Kesehatan, 2004, Pedoman Pengelolaan Obat Publik dan Perbekalan Kesehatan di Puskesmas, Departemen Kesehatan Republik Indonesia, Jakarta, hal. 10.

${ }^{188}$ Ibid., hal. 11. adalah obat esensial yang jenis dan itemnya ditentukan setiap tahun oleh Menteri Kesehatan dengan merujuk kepada Daftar Obat Esensial Nasional. Permintaan obat untuk mendukung pelayanan obat di masingmasing Puskesmas diajukan oleh Kepala Puskesmas kepada Kepala Dinas Kesehatan Kabupaten/Kota dengan menggunakan format LPLPO, sedangkan permintaan dari sub unit ke Kepala Puskesmas dilakukan secara periodik menggunakan LPLPO Sub Unit. Tujuan dari permintaan obat adalah untuk memenuhi kebutuhan obat di masing-masing unit pelayanan kesehatan sesuai dengan pola penyakit yang ada di wilayah kerjanya.

3) Penerimaan, adalah suatu kegiatan dalam menerima obat-obatan yang diserahkan dari unit pengelola yang lebih tinggi kepada unit pengelola di bawahnya. ${ }^{189}$ Setiap penyerahan obat oleh UPOPPKn kepada Puskesmas dilaksanakan setelah mendapat persetujuan dari Kepala Dinas Kabupaten/Kota atau pejabat yang diberi wewenang untuk itu. Semua petugas yang terlibat dalam kegiatan pengelolaan obat bertanggung jawab atas ketertiban penyimpanan, pemindahan, pemeliharaan dan penggunaan obat berikut kelengkapan catatan yang menyertainya. Petugas penerimaan obat wajib melakukan pengecekan terhadap obatobat yang diserahkan,

${ }^{189}$ Ibid., hal. 15. 
mencakup jumlah

kemasan/peti, jenis dan jumlah obat, bentuk obat sesuai dengan isi dokumen (LPLPO) dan ditanda tangani oleh petugas penerima/diketahui Kepala Puskesmas. Bila tidak memenuhi syarat, petugas penerima dapat mengajukan keberatan. Jika terdapat kekurangan, penerima obat wajib menuliskan jenis yang kurang (rusak, jumlah kurang, dIII). Setiap penambahan obat-obatan dicatat dan dibukukan pada buku penerimaan obat dan kartu stok. Tujuan dari penerimaan obat adalah agar obat yang diterima sesuai dengan kebutuhan berdasarkan permintaan yang diajukan oleh Puskesmas.

4) Penyimpanan obat, merupakan suatu kegiatan pengamanan terhadap obat-obatan yang diterima agar aman, terhindar dari kerusakan fisik maupun kimia dan mutunya tetap terjamin. ${ }^{190} \quad$ Tujuan penyimpanan obat meliputi memelihara mutu obatobatan, menghindari penggunaan yang tidak bertanggung jawab, menjaga kelangsungan persediaan dan memudahkan pencarian dan pengawasan.

5) Distribusi, adalah kegiatan pengeluaran dan penyerahan obat secara merata dan teratur untuk memenuhi kebutuhan subsub unit pelayanan kesehatan, antara lain: ${ }^{191}$ sub unit pelayanan kesehatan di lingkungan Puskesmas (kamar obat, laboratorium), Puskesmas Pembantu, Poliklinik Kesehatan Desa, Posyandu, dan Puskesmas Keliling. Tujuan dari distribusi obat adalah untuk memenuhi kebutuhan obat sub unit pelayanan kesehatan yang ada di wilayah kerja Puskesmas dengan jenis, mutu, jumlah dan tepat waktu.

6) Pengendalian obat, terdiri dari pengendalian persediaan, pengendalian penggunaan dan penanganan obat hilang. ${ }^{192}$ Pengendalian persediaan adalah suatu kegiatan untuk memastikan tercapainya sasaran yang diinginkan sesuai dengan strategi dan program yang telah ditetapkan sehingga tidak terjadi kelebihan dan kekurangan/kekosongan obat di unit pelayanan kesehatan dasar. Pengendalian penggunaan mempunyai tujuan untuk menjaga kualitas pelayanan obat dan meningkatkan efisiensi pemanfaatan dana obat. Pengendalian penggunaan meliputi prosentase penggunaan antibiotik, prosentase penggunaan injeksi, prosentase rata-rata jumlah resep, prosentase penggunaan obat generik, dan kesesuaian dengan pedoman. Instrumen yang digunakan adalah menggunakan format monitoring peresepan. Penanganan obat hilang mempunyai tujuan sebagai bukti pertanggungjawaban Kepala Puskesmas sehingga diketahui persediaan obat saat itu. Kejadian obat hilang dapat terjadi karena adanya

\footnotetext{
190 Ibid., hal. 16.

191 Ibid., hal. 24.
}

192 Ibid., hal. 26. 
peristiwa pencurian obat dari tempat penyimpanannya oleh pihak-pihak yang tidak bertanggung jawab. Obat juga dinyatakan hilang apabila jumlah obat dalam tempat penyimpanannya ditemukan kurang dari catatan sisa stok pada kartu stok yang bersangkutan. Pengujian silang antara jumlah obat dalam tempat penyimpanannya dengan catatan sisa stok pada kartu stok perlu dilakukan secara berkala, paling tidak 3 (tiga) bulan sekali. Pengujian semacam ini harus dilakukan oleh Kepala Puskesmas.

7) Pencatatan dan Pelaporan, merupakan rangkaian kegiatan dalam rangka penatalaksanaan obatobatan secara tertib, baik obat-obatan yang diterima, disimpan, didistribusikan dan digunakan di Puskesmas dan atau unit pelayanan lainnya. ${ }^{193}$

Puskesmas bertanggung jawab atas terlaksananya pencatatan dan pelaporan obat yang tertib dan lengkap serta tepat waktu untuk mendukung pelaksanaan seluruh pengelolaan obat. Sarana yang digunakan untuk pencatatan dan pelaporan obat di Puskesmas adalah LPLPO dan kartu stok. LPLPO yang dibuat oleh petugas Puskesmas harus tepat data, tepat isi, dan dikirim tepat waktu serta disimpan dan diarsipkan dengan baik. LPLPO juga dimanfaatkan untuk analisis penggunaan, perencanaan kebutuhan obat, pengendalian

193 Ibid., hal. 42. persediaan dan pembuatan laporan pengelolaan obat.

Ditinjau dari penelitian lapangan dan wawancara, pengelolaan obat dan bahan medis habis pakai yang dilakukan tenaga kefarmasian di Puskesmas Kabupaten Purbalingga sudah sesuai dengan Peraturan Menteri Kesehatan Republik Indonesia Nomor 30 tahun 2014 tentang Standar Pelayanan Kefarmasian di Puskesmas, dan teknis pelaksanaan sudah sesuai dengan pedoman yang berlaku. Masalah kekurangan dan kekosongan beberapa jenis obat yang terjadi di Puskesmas Kabupaten Purbalingga dapat menjadi hambatan dalam memberikan pelayanan kesehatan.

Menurut Yohanes Wahyu Waluyo, ${ }^{194}$ masalah yang terjadi dalam pengelolaan obat dan bahan medis habis pakai saat ini adalah tingkat ketersediaan obat yang masih belum sesuai dengan kebutuhan pelayanan kesehatan, yaitu di satu sisi adanya kekosongan obat danndi sisi lainnya adanya kelebihan obat. Di dalam perencanaanmkebutuhan obat di Puskesmas, terdapat proses seleksi obat yang mengacu pada Daftar Obat Esensial Nasional

${ }^{194}$ Yohanes Wahyu Waluyo, dkk, 2015, Analisis Faktor Yang Mempengaruhi Pengelolaan Obat Publik di Instalasi Farmasi Kabupaten, Jurnal IImu Kefarmasian Indonesia Vol. 13 No. 1, hal. 94, diakses pada tanggal 6 Mei 2017. 
1193 | Jurnal Idea Hukum

Vol. 4 No. 2 Oktober 2018

Magister Hukum Fakultas Hukum Universitas Jenderal Soedirman

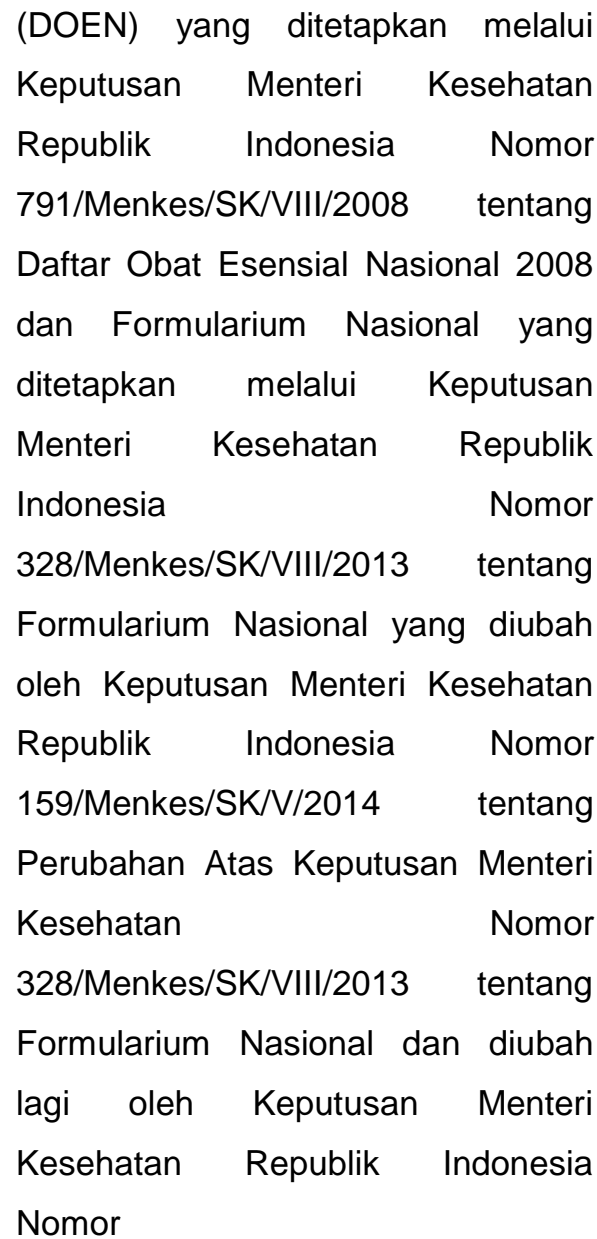

HK.02.02/Menkes/SK/363/2015

tentang Perubahan Kedua Atas

Keputusan Menteri Kesehatan

Nomor 159/Menkes/SK/V/2014

tentang Formularium Nasional.

Formularium

Nasional

mengaturtentang jenis dan sediaan

obat yang dapat disediakan di

fasilitas pelayanan kesehatan tingkat

pertama, kedua dan ketiga.

Terjadinya kekosongan dan

kelebihan obat di Puskesmas

merupakan suatu kesalahan (error)

yang dilakukan oleh tenaga

kefarmasian. Error adalah

ketidakberhasilan untuk

menyelesaikan suatu tindakan yang disebabkan oleh karena adanya kekeliruan dalam penilaian, penggunaan suatu rencana yang keliru, kekeliruan yang disebabkan oleh manusia dan sistem. ${ }^{195}$ Error diklasifikasikan menjadi tiga tipe, yaitu: skill-based slips and lapses, rule-based mistakes dan knowledgebased mistakes. Johnstone dan Kanitsaki (2006) menyatakan bahwa sebenarnya error itu dapat dicegah dengan jalan merancang sistem yang membuat orang sulit untuk membuat kesalahan dan mempermudah orang untuk melakukan hal yang benar. ${ }^{196}$ Suatu penelitian menyatakan bahwa penyebab dari error berasal dari kesalahan teknis (44\%), keliru mendiagnosa (17\%), dan kegagalan mencegah luka (12\%). Error tidak akan bias dihilangkan dari praktik medis dan kesehatan, hanya harus diusahakan terjadinya seminimal mungkin. Apabila error itu terulang lagi, maka ini bisa menjadi kelalaian medis.

\section{Kepastian Hukum Tenaga} Kefarmasian Yang Menjalankan Pelayanan Kefarmasian di Puskesmas

Asas legalitas merupakan salah satu prinsip utama yang dijadikan sebagai dasar dalam setiap penyelenggaraan pemerintahan dan kenegaraan di setiap negara hukum terutama bagi negara-negara hukum

\footnotetext{
${ }^{195}$ Cecep Triwibowo, Op.Cit., hal. 280.

${ }^{196}$ Ibid., hal. 281.
} 
dalam sistem kontinental. $^{197}$ Asas legalitas dalam hokum administrasi negara memiliki makna Dat het bestuur aan de wet is onderworpen (bahwa pemerintah tunduk kepada undang-undang) atau Het legaliteitsbeginsel houdt in dat alle (algemene) de burgers bindende bepalingen op de wet moeten berusten (asas legalitas menentukan bahwa semua ketentuan yang mengikat warga negara harus didasarkan pada undang-undang). Asas legalitas ini merupakan prinsip negara hukum yang sering dirumuskan secara khas dalam ungkapan Het beginsel van wetmatigheid van bestuur.

Penerapan asas legalitas menurut Indroharto akan menunjang berlakunya kepastian hukum dan kesamaan perlakuan. ${ }^{198}$ Kesamaan perlakuan terjadi karena setiap orang yang berada dalam situasi seperti yang ditentukan dalam ketentuan undang-undang itu berhak dan berkewajiban untuk berbuat seperti apa yang ditentukan dalam undangundang tersebut. Sementara itu, kepastian hukum akan terjadi karena suatu peraturan dapat membuat semua tindakan yang akan

197 Ridwan HR, 2006, Hukum Administrasi Negara, PT. Raja Grafindo Persada, Jakarta, hal. 9495.

198 Indroharto, 1993, Usaha Memahami Undang-Undang Tentang Peradilan Tata Usaha Negara, Pustaka Sinar Harapan, Jakarta, hal. 83-84. dilakukan pemerintah itu dapat diramalkan atau diperkirakan lebih dahulu, maka pada asasnya lalu dapat dilihat atau diharapkan apa yang akan dilakukan oleh aparat pemerintahan yang bersangkutan. Dengan demikian, warga masyarakat lalu dapat menyesuaikan dengan keadaan tersebut.

Di samping itu, menurut H.D. Stout, asas legalitas dimaksudkan untuk memberikan jaminan kedudukan hukum warga negara terhadap pemerintah. Pemerintah hanya dapat melakukan perbuatan hukum jika memiliki legalitas atau didasarkan pada undangundang yang merupakan perwujudan aspirasi warga negara. Dalam negara hukum demokratis, tindakan pemerintahan harus mendapatkan legitimasi dari rakyat yang secara formal tertuang dalam undangundang. Tenaga kontrak apoteker di Puskesmas Kabupaten Purbalingga diangkat dengan Surat Keputusan Kepala Dinas Kesehatan Kabupaten Purbalingga dengan pertimbangan untuk mewujudkan keseimbangan kapasitas personil dan beban pekerjaan antar bidang dan untuk memenuhi kebutuhan Puskesmas dalam rangka akreditasi.

Undang-Undang No. 5 tahun 2014 tentang Aparatur Sipil Negara (ASN), pada Pasal 2 ayat (1) menyebutkan bahwa pegawai ASN adalah Pegawai Negeri Sipil (PNS) dan Pegawai Pemerintah Dengan 


\begin{abstract}
Perjanjian Kerja (PPPK) yang diangkat oleh Pejabat Pembina Kepegawaian (PPK) dan diserahi tugas dalam suatu jabatan pemerintahan atau diserahi tugas negara lainnya dan digaji berdasarkan peraturan perundangundangan. Yang dimaksud PPK menurut Peraturan Pemerintah (PP) No. 9 tahun 2003 tentang Wewenang Pengangkatan, Pemindahan, dan Pemberhentian Pegawai Negeri Sipil pada Pasal 1 ayat (5) pada tingkat daerah Kabupaten/Kota adalah Bupati/Walikota. Dengan demikian, untuk pengangkatan tenaga non PNS di Puskesmas dimana Puskesmas merupakan institusi pemerintah harus mengacu kepadaperaturan perundangundangan agar status tenaga tersebut mempunyai kepastian hukum dalam melaksanakan pelayanan kefarmasian di fasilitas pelayanan kesehatan milik daerah.
\end{abstract}

Aspek hukum administrasi menyatakan bahwa tenaga kesehatan yang akan melakukan praktik baik di institusi kesehatan maupun mandiri wajib memiliki izin yang dikeluarkan pemerintah. ${ }^{199} \mathrm{Hal}$ ini sesuai dengan Undang-Undang Nomor 36 Tahun 2009 tentang Kesehatan pada Pasal 23 ayat (3) yang berbunyi "Dalam menyelenggarakan pelayanan

${ }^{199}$ Cecep Triwibowo, 2014, Op.Cit., hal. 262. kesehatan, tenaga kesehatan wajib memiliki izin dari pemerintah." Tenaga kefarmasian dalam menjalankan pelayanan kefarmasian di Puskesmas harus mempunyai kepastian hukum sesuai dengan tujuan dibuatnya Peraturan Menteri Kesehatan Republik Indonesia Nomor 30 Tahun 2014 tentang Standar Pelayanan Kefarmasian di Puskesmas, yaitu berupa Surat Tanda Registrasi (STR) dan Surat Izin Praktik (SIP). Tenaga kefarmasian yang bekerja pada fasilitas pelayanan kesehatan yang tidak mempunyai izin, baik STR maupun SIP, atau sudah memiliki izin tetapi izin tersebut sudah kadaluarsa, dapat dikenai sanksi hukum. ${ }^{200}$

Pelanggaran hokum administrasi merupakan jalan menuju malpraktik. Dari aspek hokum administrasi, pelanggaran hukum administrasi akan dikenai sanksi administrasi berupa pencabutan izin dan denda administrasi. Dalam hal tenaga kefarmasian yang tidak mempunyai STR dan SIP dalam pelayanan kefarmasian, pengaturan sanksi dijelaskan dalam peraturan perundangan-undangan sebagai berikut :

a. Undang-Undang Nomor 36 Tahun 2009 tentang Kesehatan pada Pasal 188 ayat (1) : "Menteri dapat mengambil tindakan administratif terhadap

${ }^{200}$ Ibid., hal. 264. 
tenaga kesehatan dan fasilitas pelayanan kesehatan yang melanggar ketentuan sebagaimana diatur dalam Undang-Undang ini," dan selanjutnya pada ayat (3) : "Tindakan administratif sebagaimana dimaksud pada ayat (1) dapat berupa peringatan secara tertulis dan pencabutan izin sementara atau izin tetap." Kemudian pada Pasal 198 : "Setiap orang yang tidak memiliki keahlian dan kewenangan untuk melakukan praktik kefarmasian sebagaimana dimaksud dalam Pasal 108 dipidana dengan pidana denda paling banyak Rp. 100.000.000,00 (seratus juta rupiah)."

b. Undang-Undang Nomor 36 Tahun 2014 tentang Tenaga Kesehatan pada Pasal 85 ayat (1) : "Setiap tenaga kesehatan yang dengan sengaja menjalankan praktik tanpa memiliki STR sebagaimana dimaksud dalam Pasal 44 ayat (1) dipidana dengan pidana denda paling banyak Rp. 100.000.000,00 (seratus juta rupiah)", dan pada Pasal 86: "Setiap tenaga kesehatan yang dengan sengaja menjalankan praktik tanpa memiliki STR sebagaimana dimaksud dalam Pasal 46 ayat (1) dipidana dengan pidana denda paling banyak Rp. 100.000.000,00 (seratus juta rupiah)."

Peraturan Menteri Kesehatan Republik Indonesia Nomor 30 tahun 2014 tentang Standar Pelayanan Kefarmasian di Puskesmas merupakan sistem hukum untuk mengatur pelayanan kefarmasian di Puskesmas. Pengertian dasar yang terkandung dalam suatu system hukum adalah sebagai berikut : $: 01$

a. Sistem itu berorientasi kepada tujuan;

${ }^{201}$ Satjipto Rahardjo, 2014, IImu Hukum, Citra Aditya Bakti, Bandung, hal. 48. b. Keseluruhan adalah lebih dari sekedar jumlah dan bagianbagiannya (wholism);

c. Suatu sistem berinteraksi dengan sistem yang lebih besar, yaitu lingkungannya (keterbukaan sistem);

d. Bekerjanya bagian-bagian dari sistem itu menciptakan sesuatu yang berharga (transformasi);

e. Masing-masing bagian harus cocok satu sama lain (keterhubungan);

f. Ada kekuatan pemersatu yang mengikat sistem itu (mekanisme kontrol).

Peraturan Menteri Kesehatan Republik Indonesia Nomor 30 tahun 2014 tentang Standar Pelayanan Kefarmasian di Puskesmas juga sudah sesuai dengan teori Lon Fuller yang menerapkan asas Principles of Legality, yaitu :

a. Sistem hukum ini mengandung peraturan-peraturan;

b. Peraturan ini mempunyai rumusan yang bisa dimengerti;

c. Peraturan ini sudah diumumkan dalam Berita Negara Republik Indonesia Nomor 906 Tahun 2014;

d. Peraturan ini tidak bertentangan dengan peraturan yang lain (tidak bertentangan dengan PP No. 51 Tahun 2009 tentang Pekerjaan Kefarmasian);

e. Peraturan ini sudah sesuai dengan yang dilakukan di Puskesmas, dalam hal ini Puskesmas di Kabupaten Purbalingga.

\section{Penutup}

\section{a. Kesimpulan}

Berdasarkan hasil penelitian

yang dilakukan, dapat diambil

kesimpulan:

1. Pelaksanaan pelayanan kefarmasian di Puskesmas diatur dalam Peraturan Menteri Kesehatan Republik 
Indonesia Nomor 30 Tahun

2014 tentang Standar

Pelayanan Kefarmasian di

Puskesmas, yang terdiri dari

pelayanan farmasi klinik dan

pengelolaan obat dan bahan

medis habis pakai. Apoteker

berperan sebagai

penanggung jawab

pelayanan kefarmasian di

Puskesmas tanpa

memandang status kontrak

maupun PNS. Kegiatan

pelayanan farmasi klinik

berupa penerimaan resep,

peracikan, pemberian obat,

pemberian informasi obat

dan konseling dapat

dilakukan dalam satu

kegiatan pada saat

pelayanan resep.

Sementara kegiatan visite,

Pemantauan Terapi Obat

(PTO), dan Monitoring Efek

Samping Obat (MESO)

dapat dilakukan dalam satu

kegiatan saat visite rawat

inap. Pada aspek

pengelolaan obat dan bahan

medis habis pakai, terdapat

kekosongan beberapa obat

akibat stok di Dinas

Kesehatan Kabupaten

Purbalingga yang kosong

dan lamanya proses

pengadaan online lewat

LKPP. Sedangkan adanya

obat kadaluwarsa di
Puskesmas berasal dari

buffer stok Provinsi dengan

masa kadaluwarsa pendek.

Teknis

pelaksanaan

pelayanan kefarmasian di

Puskesmas dapat

menggunakan pedoman

yang berlaku, yaitu

Pedoman Pengelolaan Obat

Publik dan Perbekalan

Kesehatan di Puskesmas

tahun 2004, Pedoman

Pelayanan Kefarmasian di

Puskesmas tahun 2006,

Pedoman Konseling

Pelayanan Kefarmasian di

Sarana Kesehatan tahun

2007, Pedoman

Pemantauan Terapi Obat

(PTO) tahun 2009,

Pedoman Visite tahun 2011,

dan Pedoman Monitoring

Efek Samping Obat (MESO)

Bagi Tenaga Kesehatan tahun 2012.

2. Kepastian hukum tenaga kefarmasian ditinjau dari aspek legalitas.

Pengangkatan tenaga

apoteker kontrak di

Puskesmas oleh Kepala

Dinas Kesehatan

Kabupaten merupakan

bentuk pelanggaran

administrasi. Selain itu,

tenaga kefarmasian harus

memiliki Surat Tanda

Registrasi (STR) dan Surat 


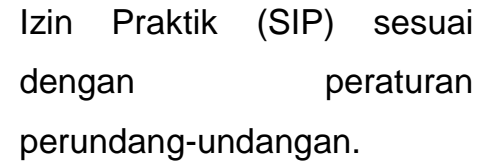

b. Saran

Berdasarkan kesimpulan di atas, maka dapat diambil saran sebagai berikut :

1. Pelayanan kefarmasian di Puskesmas harus dilaksanakan oleh tenaga kefarmasian dengan apoteker sebagai penanggung jawab.

2. Perencanaan obat dan bahan medis habis pakai agar lebih ditingkatkan untuk menghindari terjadinya kekurangan dan kekosongan obat.

3. Pengangkatan tenaga kontrak apoteker di Puskesmas harus sesuai dengan peraturan perundangundangan.

4. Diperlukan peran serta pemerintah agar setiap Puskesmas memilik tenaga apoteker.

\section{DAFTAR PUSTAKA}

Direktorat Jenderal Pelayanan Kefarmasian dan Alat Kesehatan. 2004. Pedoman Pengelolaan Obat Publik dan Perbekalan Kesehatan di Puskesmas. Departemen Kesehatan Republik Indonesia, Jakarta.

Direktorat Jenderal Bina Farmasi dan Alat Kesehatan. 2006. Pedoman Pelayanan Kefarmasian di Puskesmas.

Departemen Kesehatan Republik Indonesia, Jakarta. Direktorat
Jenderal Bina Kefarmasian dan Alat Kesehatan. 2007. Pedoman Konseling Pelayanan Kefarmasian di Saran Kesehatan. Departemen Kesehatan Republik Indonesia, Jakarta.

2009. Pedoman Pemantauan

Terapi Obat. Departemen

Kesehatan Republik Indonesia, Jakarta. 2010. Manajemen $\quad$ Kefarmasian di
Puskesmas.
Kesehatan Republik Indonesia,
Jakarta.

2011. Pedoman Visite. Kementerian Kesehatan Republik Indonesia, Jakarta.

Direktorat Pengawasan Distribusi Produk Terapetik dan PKRT. 2012. Pedoman Monitoring Efek Samping Obat (MESO) Bagi Tenaga Kesehatan. Badan POM Republik Indonesia. Jakarta.

H.R., Ridwan. 2006. Hukum Administrasi Negara. PT. Raja Grafindo Persada, Jakarta.

H.S., Salim. 2014. Penerapan Teori Hukum pada Penelitian Tesis dan Disertasi. Rajawali Pers, Jakarta.

Indroharto. 1993. Usaha Memahami Undang-Undang Tentang Peradilan Tata Usaha Negara. Pustaka Sinar Harapan, Jakarta.

Kementerian Kesehatan Republik Indonesia, 2015. Standar Pelayanan Kefarmasian di Puskesmas. Jakarta.

Muhammad, Abdulkadir. 2004. Hukum dan Penelitian Hukum. PT. Citra Aditya Bakti, Bandung.

Rahardjo, Satjipto. 2014. Ilmu Hukum. Citra Aditya Bakti, Bandung.

Siswati, Sri. 2013. Etika dan Hukum Kesehatan Dalam Perspektif Undang-Undang Kesehatan. PT. Raja Grafindo Persada, Jakarta.

Sugiyono, 2008, Memahami Penelitian Kualitatif, Alfabeta, Bandung.

Triwibowo, Cecep. 2014. Etika dan Hukum Kesehatan. Nuha Media, Yogyakarta.

Anonim. 3 Asisten Apoteker Salah Memberikan Obat Hingga Sebabkan Cedera Fisik Serius http://www.farmasetika.com>Disp ensing $>$ Edukasi, edisi 7 Februari 
1199 | Jurnal Idea Hukum

Vol. 4 No. 2 Oktober 2018

Magister Hukum Fakultas Hukum Universitas Jenderal Soedirman

2017, diakses pada tanggal $7 \mathrm{Mei}$ 2017.

Dugaan Salah Obat Pada Pasien, PMI Kalim Sudah Sesuai Aturan.

http://www.radarbanyumas.co.id., edisi Selasa 24 Mei 2016, diakses tanggal 7 Mei 2017.

Dinas Kesehatan Provinsi Jawa Tengah, Data Dasar Puskesmas dan Rumah Sakit Provinsi Jawa Tengah Tahun 2015, http://www.dinkesjatengprov.go.id ., diakses pada tanggal 3 Januari 2017.

Fadhli, Wendi Muh. dan Siti Anisah, 2016, Tanggung Jawab Hukum Dokter dan Apoteker Dalam Pelayanan Resep, Media Farmasi Vol. 13 No. 1, Maret 2016, hal. 61 s/d 87.

Mudiarta, Bagian Farmasi Salah Baca Resep.

http://www.balipost.com/news/201 7/05/04/7655, edisi Kamis 4 Mei 2017, diakses pada tanggal $7 \mathrm{Mei}$ 2017.

Purwata, Heri. Kesalahan Pemberian Obat Kepada Pasien Masih Tinggi.

http://www.republika.co.id>News> Nasional, edisi Kamis 11 Juni 2015, diakses pada tanggal $7 \mathrm{Mei}$ 2017.

Waluyo, Yohanes Wahyu, dkk, 2015, Analisis Faktor Yang Mempengaruhi Pengelolaan Obat Publik di Instalasi Farmasi Kabupaten, Jurnal IImu Kefarmasian Indonesia Vol. 13 No. 1, April 2015, hal. 94 s/d 101. 